\title{
Mechanism of the Inhibitory Action of Linoleic Acid on the Growth of Staphylococcus aureus
}

\author{
By D. L. A. GREENWAY* AND K. G. H. DYKE \\ Microbiology Unit, Department of Biochemistry, University of Oxford, South Parks Road, \\ Oxford $O X 13 Q U$
}

(Received 15 January 1979)

\begin{abstract}
Linoleic acid, but not stearic acid, inhibited the growth of Staphylococcus aureus NCTC 8325. Growth inhibition was associated with an increase in the permeability of the bacterial membrane. The presence of a plasmid conferring resistance to penicillin (PC plasmid, e.g. $\mathrm{pI}_{258}$ blaI $^{-}$) increased the growth inhibitory and membrane permeability effects of linoleic acid. Under growth inhibitory conditions, linoleic acid was incorporated into the lipid of both PC plasmid-containing and PC plasmid-negative bacteria and there was little difference between these cultures in the uptake or fate of linoleic acid. Experiments using a glycerol auxotroph of $S$. aureus suggested that free linoleic acid, rather than lipid containing this acid, inhibits growth. Linoleic acid probably inhibits growth by increasing the permeability of the bacterial membrane as a result of its surfactant action, and the presence of the PC plasmid increases these effects.
\end{abstract}

\section{INTRODUCTION}

The growth of Gram-positive bacteria is usually inhibited by long-chain fatty acids to a greater extent than that of Gram-negative bacteria (Nieman, 1954). Galbraith \& Miller $(1973 a, b, c)$ have shown that long-chain fatty acids are bactericidal for Gram-positive bacteria, causing lysis of osmotically stabilized protoplasts, leakage of $260 \mathrm{~nm}$-absorbing material and protein from both bacteria and protoplasts, and inhibition of both respiration (oxygen uptake) and amino acid uptake. Similar results have been reported for Bacillus subtilis (Sheu \& Freese, 1973; Freese et al., 1973; Sheu et al., 1975).

Both groups have suggested (Galbraith et al., 1971; Galbraith \& Miller, 1973c; Sheu \& Freese, 1973; Sheu et al., 1975) that the large difference in the fatty acid sensitivities between Gram-positive and Gram-negative bacteria may result from the outer membrane preventing fatty acids reaching the inner, fatty acid-sensitive cytoplasmic membrane of Gram-negative bacteria. Nikaido (1976) has shown that the outer membrane of Salmonella typhimurium is an effective barrier against hydrophobic substances whereas the cytoplasmic membrane of spheroplasts from it is very permeable. The impermeability of the outer membrane appears to be related to the structure of the lipopolysaccharide molecules. 'Deep rough' mutants which have lost 80 to $90 \%$ of the carbohydrate portion of the lipopolysaccharide molecule have greatly increased sensitivity towards certain hydrophobic antibiotics and dyes (Roantree et al., 1969; Schlecht \& Schmidt, 1970; Schmidt et al., 1969).

Butcher et al. (1976) have shown that the growth of Staphylococcus aureus is inhibited by long-chain cis unsaturated fatty acids (UFAs) and that the presence of a plasmid conferring resistance to penicillin (PC plasmid) enhanced the sensitivity of $S$. aureus to UFAs. The

\footnotetext{
* Present address: Department of Biological Chemistry, Washington University School of Medicine, 660 South Euclid Avenue, St Louis, Missouri 63110, U.S.A.
} 
aims of the present work were to investigate further the effects of UFAs on S. aureus and to examine how the PC plasmid increases the UFA sensitivity of the bacterium.

\section{METHODS}

Bacteria. Staphylococcus aureus NCTC 8325 was used for most of these studies and was designated $8325(\mathrm{~N})$ to indicate that it does not contain a known plasmid. Staphylococcus aureus $8325\left(\mathrm{pI}_{258}\right)$ was constructed by transduction selecting for erythromycin resistance from S. aureus $258\left(\mathrm{pI}_{258}\right)$ (Mitsuhashi et al., 1965) to S. aureus $8325(\mathrm{~N})$. A strain producing penicillinase constitutively has been isolated from $8325\left(\mathrm{pI}_{258}\right)$ after ethyl methanesulphonate mutagenesis (K. G. H. Dyke \& H. Hackling, unpublished) and designated 8325$\left(\mathrm{pI}_{258} b l a \mathrm{I}^{-}\right)$. Isogenic $8325(\mathrm{~N})$ and $8325\left(\mathrm{pI}_{258} b l a \mathrm{I}^{-}\right)$strains (except for the $\mathrm{pI}_{258}$ blaI- PC plasmid) were constructed by transduction selecting for cadmium ion resistance from $8325\left(\mathrm{pI}_{258}\right.$ blaI $\left.^{-}\right)$to a culture derived from a single colony of $8325(\mathrm{~N})$, according to the method of Johnston \& Dyke (1971) using phage 53 of the International Set of Typing Phages. This strain is resistant to cadmium ions, erythromycin, arsenate ions and produces penicillinase constitutively; it is assumed to carry the entire plasmid. Staphylococcus aureus 147-92 and 147-92 S4glyc were kindly given by Dr L. Mindich (Department of Microbiology, Public Health Research Institute of the City of New York, N.Y. 10016, U.S.A.). Staphylococcus aureus 147-92 S4glyc is a glycerol auxotroph requiring $20 \mu \mathrm{g}$ glycerol ml ${ }^{-1}$ for normal growth (Mindich, 1971).

Growth of bacteria. CY medium (Novick, 1963) was used except in experiments involving the glycerol auxotroph when SNMM medium was used (Mindich, 1971). Growth was followed by measuring the absorbance at $675 \mathrm{~nm}$ in a $1 \mathrm{~cm}$ path-length cuvette in a Unicam SP600 spectrophotometer. All experiments were conducted at $30^{\circ} \mathrm{C}$.

Growth inhibition was measured as follows. A culture of stationary phase bacteria was diluted into fresh warm medium to give an $A_{675}$ of 0.05 to 0.1 . The bacteria were grown with shaking for three generations to approximately mid-exponential phase and then diluted to an $A_{675}$ of 0.2 with fresh warm medium. The diluted culture was added to flasks containing twice the desired concentration of fatty acid in CY medium plus $2 \%(\mathrm{v} / \mathrm{v})$ ethanol, to give a final $A_{675}$ of $0 \cdot 1$. The mean generation time (MGT) was measured and growth inhibition was calculated from:

$$
\text { Growth inhibition }(\%)=\left(1-\frac{\text { MGT, control culture }}{\text { MGT, treated culture }}\right) \times 100
$$

Broth media were solidified by adding $1.5 \%$ (w/v) agar (Difco Bacto). Strains carrying the PC plasmid were maintained on $\mathrm{CY}$ agar containing $13 \cdot 3 \mu \mathrm{g}$ cadmium acetate $\mathrm{ml}^{-1}$.

Measurement of macromolecular syntheses. DNA, RNA, cell wall, protein and membrane synthesis were measured by monitoring the incorporation of $\left[2-{ }^{14} \mathrm{C}\right]$ thymidine, $\left[5-{ }^{3} \mathrm{H}\right]$ uracil, $\left[2-{ }^{3} \mathrm{H}\right] \mathrm{glycine}, \mathrm{L}-\left[\mathrm{U}-{ }^{14} \mathrm{C}\right]-$ phenylalanine and $\left[2{ }^{3} \mathrm{H}\right] \mathrm{glycerol}$, respectively, into material precipitated by ice-cold $5 \%(\mathrm{w} / \mathrm{v})$ trichloroacetic acid (TCA). Since glycine is incorporated into both cell wall and protein, but phenylalanine only into protein (Hancock \& Park, 1958), the study of incorporation of these two precursors allows the measurement of protein synthesis and cell wall synthesis. In conditions of growth, Hancock \& Park (1958) found that $36 \%$ of the glycine was incorporated into protein and $64 \%$ into mucopeptide. Samples were mixed with an equal volume of ice-cold $10 \%(\mathrm{w} / \mathrm{v}) \mathrm{TCA}$, and after 60 to $120 \mathrm{~min}$ at $0{ }^{\circ} \mathrm{C}$ they were filtered through glass-fibre filters (Whatman GF/C, $2.5 \mathrm{~cm}$ diam.). The filters were washed with $4 \times 5 \mathrm{ml}$ ice-cold $5 \%(\mathrm{w} / \mathrm{v}) \mathrm{TCA}$ and then with $4 \times 5 \mathrm{ml}$ ethanol. The filters were placed in glass vials, dried in vacuo for $1 \mathrm{~h}$ at $80^{\circ} \mathrm{C}$ and radioactivity was determined.

Uptake and incorporation of $\left[11^{14} \mathrm{C}\right]$ linoleic acid. (i) Uptake into whole bacteria. Samples of bacteria, growing exponentially, were rapidly filtered through Millipore filters $(2.5 \mathrm{~cm}$ diam., $0.45 \mu \mathrm{m}$ pore size) and washed with 20 sample volumes of $0 \cdot 1 \mathrm{M}$-phosphate buffer, pH 7.0, containing $1 \%(\mathrm{v} / \mathrm{v})$ Triton X-100. The filters were than placed in glass vials, dried and counted.

(ii) Incorporation into macromolecules. The method used was essentially that described above for incorporation of other precursors into TCA-precipitated material, except that the precipitates were washed with $4 \times 5 \mathrm{ml}$ ice-cold $5 \%(\mathrm{w} / \mathrm{v})$ TCA containing $0.5 \%(\mathrm{w} / \mathrm{v})$ Brij-35, followed by ethanol.

The inclusion of detergents in the washes is necessary to remove linoleic acid which is bound to the filters. Control experiments with bacterial samples whose lipids and proteins were radioactively labelled showed that neither macromolecular species was removed by the detergent washes.

Radioactivity was measured after adding $2.5 \mathrm{ml}$ scintillation fluid [2-(4'-tert-butylphenyl)-5-(4"-biphenylyl)1,3,4-oxadiazole, $5 \mathrm{~g} \mathrm{1}^{-1}$ in toluene] to each sample vial, using a Wallac LKB liquid scintillation counter (model 81000). To determine the radioactivity of liquid or aqueous samples, $100 \mu \mathrm{l}$ portions were placed on GF/C filters that were than dried and counted as previously described.

Oxygen uptake measurements. The oxygen uptake of bacterial suspensions was measured using a Clark- 
type oxygen electrode (Rank Bros, Bottisham, Cambs.). The apparatus had a volume of $3 \mathrm{ml}$ and was maintained at $30^{\circ} \mathrm{C}$. A suspension $(3 \mathrm{ml}$ ) of exponentially growing bacteria (as described for growth inhibition studies) in CY medium $\left(A_{675} 0 \cdot 2\right)$ was placed inside the electrode and the rate of oxygen uptake was measured. Additions were made through a fine hole in the top of the electrode. Linoleic acid was added in a small volume of ethanol. The electrode was calibrated with air-saturated buffer at $30^{\circ} \mathrm{C}$, assumed to contain oxygen at a concentration of $0.47 \mu \mathrm{g}$ atom $\mathrm{ml}^{-1}$ (Kaye \& Laby, 1966).

Extraction of lipid from bacteria. The lipids of $S$. aureus were extracted by the method of White \& Frerman (1967).

Thin-layer chromatography (t.l.c.). Separations were carried out on silica gel G t.l.c. plates (Merck, $20 \times 20$ $\mathrm{cm}, 250 \mu \mathrm{m}$ thick thin-layer) which had been previously activated for $30 \mathrm{~min}$ at $100{ }^{\circ} \mathrm{C}$. Samples, together with appropriate standards, were applied to the thin layers. After development, components were visualized by exposure to iodine vapour and the spots were traced. Two different developing solvents were used for methyl linoleate extract analyses: (a) hexane/diethyl ether/acetic acid $(70: 30: 2$, by vol.); (b) hexane/ethanol (3:1, by vol.). Membrane lipid extracts were developed with $\mathrm{CHCl}_{3} / \mathrm{CH}_{3} \mathrm{OH} / \mathrm{H}_{2} \mathrm{O} /$ acetic acid $(65: 25: 4: 1$, by vol.). After autoradiography, the lipid separations were analysed by using the spray reagents of Dittmer \& Lester (1964).

Autoradiography of t.l.c. plates was performed by using Kodak 'Non-screen' X-ray film placed on top of thoroughly dried plates. Exposure time was usually 5 to $7 \mathrm{~d}$. For some experiments radioactive areas, identified by autoradiography, were scraped off and counted.

Leakage of $260 \mathrm{~nm}$-absorbing material from bacteria. This was measured using a method modified from that described by Salton (1951). Bacteria grown to mid-exponential phase $\left(A_{675} 0 \cdot 8\right)$ as previously described were harvested by centrifugation $(5000 \mathrm{~g}$ for $15 \mathrm{~min})$, washed three times in ice-cold $50 \mathrm{mM}-\mathrm{Tris} / \mathrm{HCl}$ buffer, $\mathrm{pH} 7 \cdot 5$, and resuspended in similar buffer $\left(A_{675}\right.$ about $15 ; 6 \mathrm{mg}$ dry wt $\left.\mathrm{ml}^{-1}\right)$. The bacterial suspensions were diluted five fold into buffer at $30^{\circ} \mathrm{C}$ containing various concentrations of fatty acids, added in a small volume of ethanol (final concn, $1 \%, \mathrm{v} / \mathrm{v}$ ). After the appropriate time, $5 \mathrm{ml}$ of these suspensions was pipetted into centrifuge tubes, cooled rapidly to $0{ }^{\circ} \mathrm{C}$ and centrifuged. One $\mathrm{ml}$ of the supernatant was then carefully removed and after dilution into absolute ethanol, the $A_{260}$ was measured. Dilution with ethanol was necessary to avoid precipitation of linoleic acid at high concentrations in aqueous solution. The total amount of $260 \mathrm{~nm}$-absorbing material present in the bacteria was measured by diluting bacterial samples fivefold into buffer and boiling for $15 \mathrm{~min}$. The samples were then cooled, centrifuged and $A_{260}$ of the supernatant was measured as described above.

Chemicals. All chemicals used were the best grade commercially available. Linoleic acid and stearic acid were obtained from Sigma and were used without further purification. Solvents were redistilled before use. All radiochemicals were obtained from The Radiochemical Centre, Amersham.

\section{RESULTS}

\section{Effect of linoleic and stearic acids on growth}

Linoleic acid $\left(\mathrm{C}_{18: 2}\right)$ inhibited the growth of $S$. aureus whereas the fully saturated stearic acid $\left(\mathrm{C}_{18: 0}\right)$ at similar concentrations did not (Fig. 1). Strain $8325\left(\mathrm{pI}_{258}\right.$ blaI $\left.\mathrm{I}^{-}\right)$was more sensitive to the effects of linoleic acid than strain $8325(\mathrm{~N})$.

\section{Effect of linoleic acid on macromolecular synthesis}

The effect of linoleic acid on the incorporation of the following radioactive precursors into macromolecules was studied: RNA synthesis, [5- $\left.{ }^{3} \mathrm{H}\right]$ uracil $\left(20 \mu \mathrm{g}, 1 \mu \mathrm{Ci} \mathrm{ml}{ }^{-1}\right)$; DNA synthesis, $\left[2-{ }^{-14} \mathrm{C}\right]$ thymidine $\left(10 \mu \mathrm{g}, 0.05 \mu \mathrm{Ci} \mathrm{m}^{-1}\right)$; protein synthesis, L-[U-14 $\left.\mathrm{C}\right]$ phenylalanine $\left(10 \mathrm{mg}, 0 \cdot 1 \mu \mathrm{Ci} \mathrm{ml}^{-1}\right)$; cell wall synthesis, $\left[2-^{3} \mathrm{H}\right] \mathrm{glycine}\left(20 \mu \mathrm{g}, 1 \mu \mathrm{Ci} \mathrm{ml}^{-1}\right)$; membrane synthesis, $\left[2{ }^{-3} \mathrm{H}\right]$ glycerol $\left(1 \mu \mathrm{Ci} \mathrm{ml}^{-1}\right)$. Linoleic acid affected similarly the synthesis of protein, cell wall, RNA, DNA or membrane in both S. aureus $8325(\mathrm{~N})$ and $8325\left(\mathrm{pI}_{258}\right.$ bla $\left.\mathrm{I}^{-}\right)$. Results are shown for protein synthesis (Fig. 2). The inhibition was proportional to the inhibition of growth as measured by the increase in $A_{675}$.

\section{Effect of linoleic acid on oxygen uptake}

Since linoleic acid did not preferentially affect any of the types of macromolecular synthesis studied, the linoleic acid-sensitive reaction may be common to all these syntheses, the most obvious being the supply of energy. Linoleic acid inhibited the uptake of oxygen 


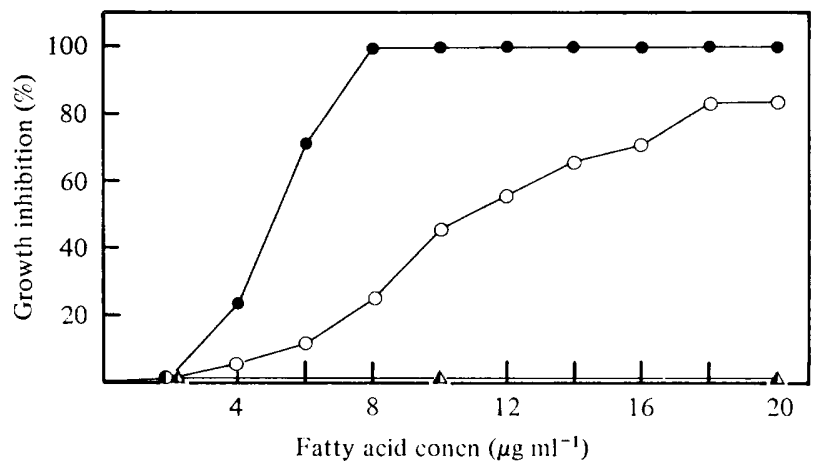

Fig. 1. Effect of linoleic and stearic acids on the growth of S. aureus $8325(\mathrm{~N})$ and $8325\left(\mathrm{pI}_{258} b l a \mathrm{I}^{-}\right)$. Cultures of stationary phase bacteria were diluted into fresh warm CY medium to an $A_{675}$ of 0.1 and grown at $30^{\circ} \mathrm{C}$ for three generations. The cultures were then diluted to $5 \times 10^{7}$ colony-forming units $\mathrm{ml}^{-1}$ with $\mathrm{CY}$ medium and linoleic or stearic acid was added [final ethanol concn $1 \%(\mathrm{v} / \mathrm{v})$ ]. Growth inhibition was measured as described in Methods. Linoleic acid: $\mathrm{O}, 8325(\mathrm{~N})$; $0,8325-$ $\left(\mathrm{pI}_{258}\right.$ blaI $\left.^{-}\right)$. Stearic acid: $\triangle, 8325(\mathrm{~N}) ; \Delta, 8325\left(\mathrm{pI}_{258} b l a \mathrm{I}^{-}\right)$.

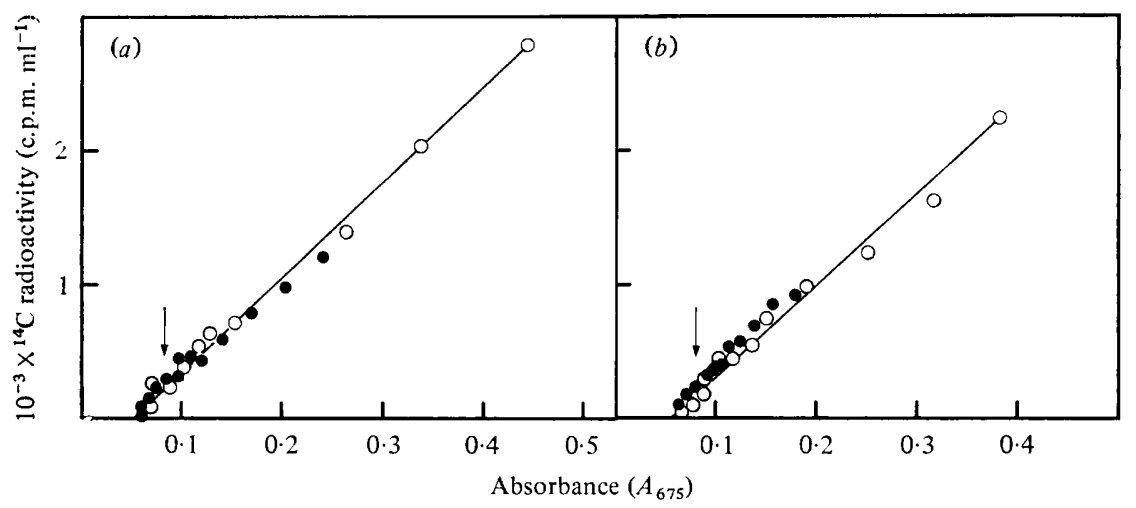

Fig. 2. Effect of linoleic acid on macromolecular synthesis in $S$. aureus $8325(\mathrm{~N})\left(\right.$ a) and $8325\left(\mathrm{pI}_{258^{-}}\right.$ blal $\left.{ }^{-}\right)(b)$. Cultures of stationary phase bacteria grown at $30^{\circ} \mathrm{C}$ were diluted into fresh warm CY medium (supplemented with phenylalanine, $10 \mu \mathrm{g} \mathrm{ml}^{-1}$ ) to an $A_{675}$ of $0 \cdot 1$ and grown for three generations. The cultures were then diluted to an $A_{675}$ of 0.05 and $1 \mu \mathrm{Ci} \mathrm{L}-\left[\mathrm{U}-{ }^{14} \mathrm{C}\right]$ phenylalanine $\mathrm{ml}^{-1}$ was added. The incorporation of radioactivity into ice-cold $5 \%(\mathrm{w} / \mathrm{v})$ TCA-precipitated material was followed for approximately $40 \mathrm{~min}$ until the $A_{675}$ was about $0 \cdot 1$. At this point (arrowed) linoleic acid was added [final concn $5 \mu \mathrm{g} \mathrm{ml}^{-1}$ for $8325(\mathrm{~N})$ and $3 \mu \mathrm{g} \mathrm{ml}^{-1}$ for $8325\left(\mathrm{pl}_{258} b\right.$ ba $\left.\mathrm{I}^{-}\right)$; final ethanol concn $1 \%(\mathrm{v} / \mathrm{v})]$ to one flask, and the same volume of ethanol was added to a control flask. Growth and incorporation of precursor into TCA-precipitated material was followed for a further $120 \mathrm{~min}$. Growth inhibition was $36 \%$ for $8325(\mathrm{~N})$ and $38 \%$ for $8325\left(\mathrm{pI}_{258} b l a I^{-}\right)$. $\mathrm{O}$, Control; e, with linoleic acid.

by suspensions of $S$. aureus in the mid-exponential phase of growth (Fig. 3). The extent of this inhibition correlated with growth of both $8325(\mathrm{~N})$ and $8325\left(\mathrm{pI}_{258}\right.$ bla $\left.\mathrm{I}^{-}\right)$as did the inhibition of synthesis of macromolecules.

\section{Uptake of linoleic acid}

An explanation for the increased sensitivity of PC plasmid-containing bacteria was sought by studying the uptake of $\left[1-{ }^{14} \mathrm{C}\right]$ linoleic acid into both whole bacteria and TCA precipitates. There was little difference in the initial rate of uptake into either whole bacteria or TCA precipitates (Fig. 4). Calculation of $K_{\mathrm{m}}$ and $V_{\max }$ values by the method of Eisenthal $\&$ Cornish-Bowden (1974) revealed a small difference between the uptake system of $S$. aureus $8325\left(\mathrm{pI}_{258}\right.$ blaI $\left.^{-}\right)\left[K_{\mathrm{m}} 1.98 \mu \mathrm{M} ; V_{\max } 0.18 \mu \mathrm{g}\right.$ linoleic acid $\left.\min ^{-1}(\mathrm{mg} \text { dry wt bacteria })^{-1}\right]$ 


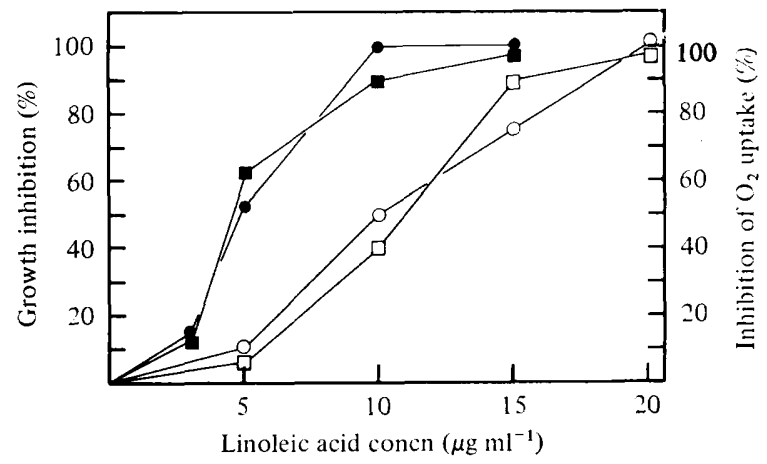

Fig. 3. Inhibition by linoleic acid of oxygen uptake and growth. Cultures of stationary phase $S$. aureus $8325(\mathrm{~N})$ and $8325\left(\mathrm{pI}_{258}\right.$ bla $\left.\mathrm{I}^{-}\right)$grown at $30^{\circ} \mathrm{C}$ were diluted into fresh warm $\mathrm{CY}$ medium to an $A_{675}$ of $0 \cdot 1$. The cultures were grown for three generations, and then diluted to an $A_{675}$ of 0.2 . Samples $(3 \mathrm{ml})$ of these cultures were added to a Clark-type oxygen electrode, maintained at $30^{\circ} \mathrm{C}$, and the rate of oxygen uptake was measured. Linoleic acid in a small volume of ethanol was then added [final ethanol concn $1 \%(\mathrm{v} / \mathrm{v})$ ] and the new rate of oxygen uptake was measured. Growth inhibition was determined as described in Fig. 1. Growth inhibition: $\bigcirc, 8325(\mathrm{~N})$;, $8325-$ $\left.\left(\mathrm{pI}_{258} \text { blaI }\right)^{-}\right)$. Oxygen uptake inhibition: $\square, 8325(\mathrm{~N}) ; \square, 8325\left(\mathrm{pI}_{258} b_{l a I^{-}}\right)$.

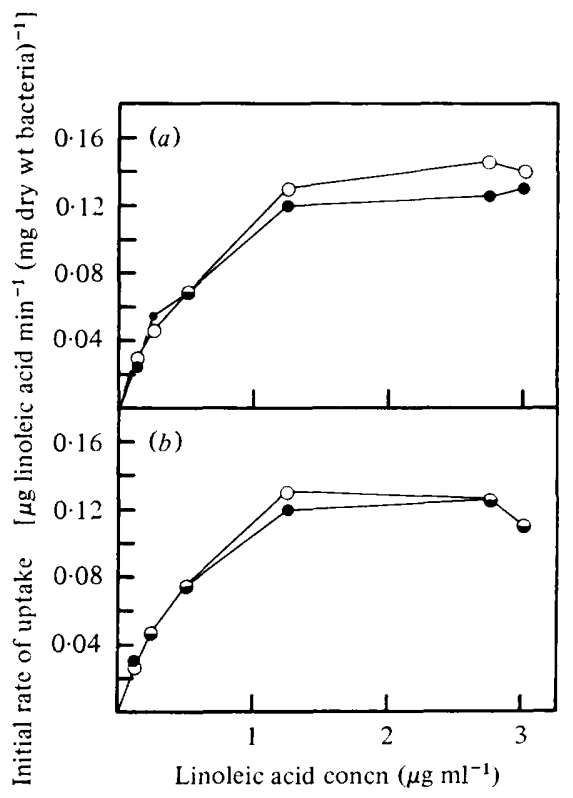

Fig. 4. Uptake of linoleic acid by $S$. aureus $8325(\mathrm{~N})($ a $)$ and $8325\left(\mathrm{pI}_{258}\right.$ bla $\left.\mathrm{I}^{-}\right)($b) . Cultures of stationary phase bacteria grown at $30^{\circ} \mathrm{C}$ in $\mathrm{CY}$ medium were diluted into fresh warm $\mathrm{CY}$ medium to an $A_{675}$ of $0 \cdot 1$ and grown at $30^{\circ} \mathrm{C}$ for three generations. The cultures were then diluted with fresh CY medium to an $A_{675}$ of $0 \cdot 1$, and linoleic acid was added together with $0 \cdot 1 \mu \mathrm{Ci}\left[1-{ }^{14} \mathrm{C}\right] l$ inoleic acid ml ${ }^{-1}$. [In experiments where low concentrations of linoleic acid $\left(0.25\right.$ and $\left.0.125 \mu \mathrm{g} \mathrm{ml}^{-1}\right)$ were used, [1-14 C]linoleic acid was present at 0.05 and $0.025 \mu \mathrm{Ci} \mathrm{ml}^{-1}$, respectively.] Uptake into whole bacteria or acid-precipitated material was measured at $30^{\circ} \mathrm{C}$ for 6 to $10 \mathrm{~min}$. Duplicate $1 \mathrm{ml}$ samples of culture were pipetted either on to a Millipore filter $(0.45 \mu \mathrm{m}$ pore diam.) followed by washing with 20 vol. $0 \cdot 1 \mathrm{M}$-phosphate buffer, pH 7.0, containing $1 \%(\mathrm{v} / \mathrm{v})$ Triton $\mathrm{X}-100$, or into $1 \mathrm{ml} 10 \%(\mathrm{w} / \mathrm{v})$ ice-cold trichloroacetic acid (TCA). The TCA-precipitated material was collected on a Whatman GF/C filter, washed with $4 \times 5 \mathrm{ml}$ ice-cold $5 \%(\mathrm{w} / \mathrm{v})$ TCA containing $0.5 \%(\mathrm{w} / \mathrm{v})$ Brij-35 and $4 \times 5 \mathrm{ml}$ ethanol. The filters were dried in vacuo and counted in a liquid scintillation counter. $\bigcirc$, Uptake into whole bacteria; 0 , incorporation into macromolecules. 
Table 1. Extraction of lipid from S. aureus $8325(\mathrm{~N})$ and $8325\left(\mathrm{pI}_{258}\right.$ bla $\left.\mathrm{I}^{-}\right)$grown in the presence of $\left[1{ }^{14} \mathrm{C}\right]$ linoleic acid at growth inhibitory concentrations of linoleic acid

Staphylococcus aureus $8325(\mathrm{~N})$ and $8325\left(\mathrm{pI}_{258}\right.$ bla $\left.\mathrm{I}^{-}\right)$, growing exponentially, were grown for one generation in the presence of $\left[1-{ }^{14} \mathrm{C}\right]$ linoleic acid $\left(0.5 \mu \mathrm{Ci} \mathrm{ml}{ }^{-1}\right)$ at growth inhibitory concentrations of linoleic acid [10 $\mu \mathrm{g} \mathrm{ml}^{-1}$ for $8325(\mathrm{~N})$ and $4 \mu \mathrm{g} \mathrm{ml}^{-1}$ for $8325\left(\mathrm{pI}_{258} \mathrm{blaI}^{-}\right)$]. The labelled bacteria (approx. $2.4 \mathrm{mg}$ dry wt) were mixed with bacteria grown in the presence of unlabelled linoleic acid (approx. $20 \mathrm{mg}$ dry wt) and subjected to the extraction procedure of White \& Frerman (1967), except that the bacteria were washed in $0.1 \mathrm{M}$-phosphate buffer, $\mathrm{pH} 7 \cdot 0$, containing $1 \%(\mathrm{v} / \mathrm{v})$

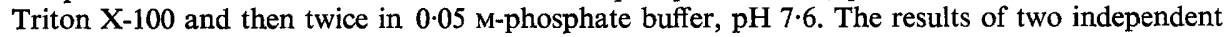
fractionations are shown.

Growth inhibition (\%)

Total c.p.m. present

C.p.m. extracted as lipid (\%)

C.p.m. remaining in aqueous phase (\%)

Recovery of c.p.m. (\%)

\begin{tabular}{|c|c|}
\hline \multicolumn{2}{|c|}{$8325(\mathrm{~N})$} \\
\hline Expt 1 & Expt 2 \\
\hline $\begin{array}{c}58 \\
678640\end{array}$ & $\begin{array}{c}50 \\
652000\end{array}$ \\
\hline $\begin{array}{c}91 \\
7 \cdot 6\end{array}$ & $\begin{array}{l}89 \\
7 \cdot 6\end{array}$ \\
\hline $98 \cdot 6$ & 96.6 \\
\hline
\end{tabular}

\begin{tabular}{|c|c|}
\hline \multicolumn{2}{|c|}{$8325\left(\mathrm{pI}_{258} b l a \mathrm{I}^{-}\right)$} \\
\hline Expt 1 & Expt 2 \\
\hline $\begin{array}{c}30 \\
2750400\end{array}$ & $\begin{array}{c}42 \\
2526200\end{array}$ \\
\hline 92 & 94 \\
\hline 3.6 & 3.7 \\
\hline 95.6 & $97 \cdot 7$ \\
\hline
\end{tabular}

and $8325(\mathrm{~N})\left[K_{\mathrm{m}} 2.25 \mu \mathrm{M} ; V_{\max } 0.168 \mu \mathrm{g}\right.$ linoleic acid $\min ^{-1}\left(\mathrm{mg}\right.$ dry wt bacteria) $\left.{ }^{-1}\right]$. Thus, the PC plasmid-containing bacteria took up linoleic acid at a slightly higher rate than the plasmid-negative bacteria.

A large amount of linoleic acid was incorporated by $S$. aureus (approximately $0.9 \%$ by weight per generation, assuming a mean generation time of $50 \mathrm{~min}$ ). To locate the incorporated radioactivity, $S$. aureus was grown in the presence of growth inhibitory concentrations of $\left[1-{ }^{14} \mathrm{C}\right]$ linoleic acid for the time necessary for the $A_{675}$ to double, and the lipids were then extracted by the method of White \& Frerman (1967). At least $89 \%$ of the total radioactivity incorporated was recovered in the lipid fraction (Table 1).

Analysis of the $\left[1-{ }^{14} \mathrm{C}\right]$ linoleic acid-labelled lipid fractions from both $S$. aureus $8325(\mathrm{~N})$ and $8325\left(\mathrm{pI}_{258}\right.$ blaI $\left.\mathrm{I}^{-}\right)$by t.l.c. revealed that radioactivity was present in lipids characteristic of $S$. aureus (Fig. 5). No free linoleic acid was detected and there were no obvious differences between the lipids derived from $8325(\mathrm{~N})$ and $8325\left(\mathrm{pI}_{258} b l a \mathrm{I}^{-}\right)$. The identity of the various species in each fraction was determined by comparison with standard lipids on the same t.l.c. plate and by spraying the plates with various diagnostic reagents (Dittmer \& Lester, 1964). The probable identity of the labelled species is as follows: Spot 1, neutral lipid, possibly glycolipid; 2, phosphatidic acid; 3 , cardiolipin; 4, phosphatidylglycerol; 5, $O$-lysyl-phosphatidylglycerol; 6 , unknown. Spots 2 and 3 gave positive reactions for the presence of phosphorus, so cannot be free linoleic acid.

The extracted radioactive lipid was subjected to acid-catalysed methanolysis, followed by extraction of methyl esters in hexane and analysis of hexane fractions by t.l.c. (Fig. 6). More than $98 \%$ of the radioactivity applied was present in the component having the same $R_{r}$ as methyl linoleate. Similar results were obtained using a second solvent system (hexane/diethyl ether/acetic acid; 70:30:1, by vol.). Thus, $\left[1-{ }^{14} \mathrm{C}\right]$ linoleic acid incorporated into the lipid of $S$. aureus $8325(\mathrm{~N})$ and $8325\left(\mathrm{pI}_{258}\right.$ blaI $\left.\mathrm{I}^{-}\right)$was essentially still linoleic acid.

The growth inhibitory component: linoleic acid itself or lipid into which linoleic acid has become incorporated

Under the conditions of growth inhibition used, linoleic acid is extensively incorporated into neutral lipids. The possibility that the incorporation into lipid is a prerequisite for the growth inhibitory action of linoleic acid was studied with the aid of a glycerol auxotroph S4 of S. aureus 147-92 (Mindich, 1971). If glycerol is removed from the growth medium, this mutant grows at the usual rate for one generation and then growth slows and subsequently stops. DNA, RNA and protein synthesis are all normal during the period of 'normal' growth, but incorporation of fatty acids into lipid stops almost completely im- 


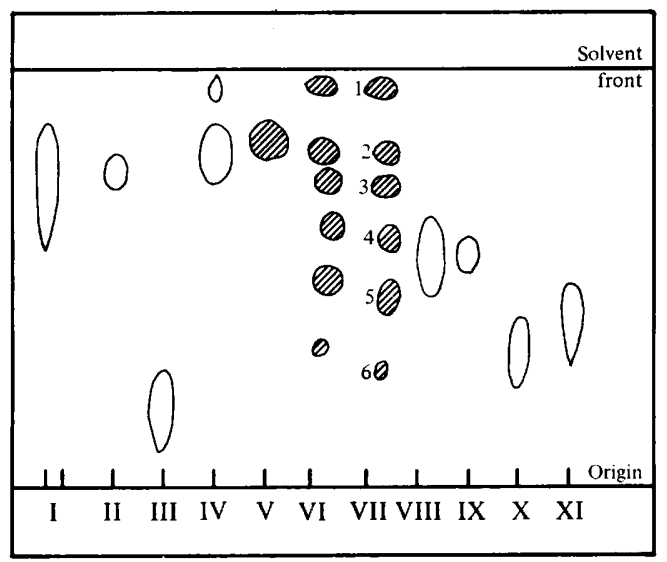

Fig. 5

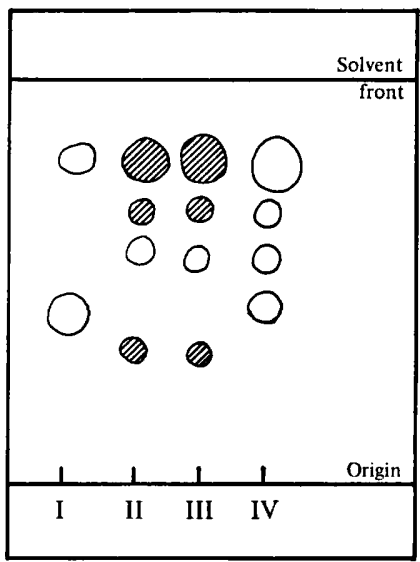

Fig. 6

Fig. 5. T.l.c. analysis of lipid extracted from $S$. aureus $8325(\mathrm{~N})$ and $8325\left(\mathrm{pl}_{258}\right.$ bla $\left.\mathrm{I}^{-}\right)$after growth in the presence of $\left[1^{-14} \mathrm{C}\right]$ linoleic acid under growth inhibitory conditions. To a culture of exponentially growing $S$. aureus $8325(\mathrm{~N})$, linoleic acid was added (final concn $10 \mu \mathrm{g} \mathrm{ml}^{-1}$ ) and incubation at $30^{\circ} \mathrm{C}$ was continued until the $A_{675}$ had doubled. Similarly, S. aureus $8325\left(\mathrm{pI}_{258} \mathrm{blaI}^{-}\right)$was grown in $4 \mu \mathrm{g}$ linoleic acid $\mathrm{ml}^{-1}$. Growth was inhibited $50 \%$ for $8325(\mathrm{~N})$ and $42 \%$ for $8325\left(\mathrm{pJ}_{258} \mathrm{blaI}^{-}\right)$. The bacteria were then harvested. Lipids extracted from the bacteria were concentrated by evaporation of excess $\mathrm{CHCl}_{3}$, and $50 \mu \mathrm{l}$ of each extract was applied to an activated silica gel $\mathrm{G}$ plate together with other standards: I, phosphatidic acid; II, cardiolipin; III, lysolecithin; IV, unlabelled linoleic acid; V, [1-14 C]linoleic acid; VI, 8325(N) lipid; VII, 8325(pI $\left.{ }_{258} b_{l a I^{-}}\right)$lipid; VIII, phosphatidylglycerol; IX, phosphatidylethanolamine; X, phosphatidylcholine; XI, phosphatidylserine. The plate was developed in $\mathrm{CHCl}_{3} / \mathrm{CH}_{3} \mathrm{OH} / \mathrm{H}_{2} \mathrm{O} /$ acetic acid $(65: 25: 4: 1$, by vol.) for $12 \mathrm{~cm}$, then dried and exposed to iodine vapour. After tracing the visible spots, the plate was autoradiographed. Finally, the plate was sprayed with $0.25 \%(\mathrm{w} / \mathrm{v})$ ninhydrin and then molybdenum blue reagent (Dittmer \& Lester, 1964). Shaded spots correspond to radioactive material as determined by autoradiography.

Fig. 6. T.1.c. analysis of material produced by methanolysis of ${ }^{14} \mathrm{C}$-labelled lipid. Lipid extracted from $S$. aureus $8325(\mathrm{~N})$ and $8325\left(\mathrm{pI}_{258}\right.$ blaI $\left.{ }^{-}\right)$after growth in the presence of $\left[1{ }^{-14} \mathrm{C}\right]$ linoleic acid was subjected to acid-catalysed methanolysis. After partition of the resulting material between hexane and saturated $\mathrm{NaCl}$ solution, samples of the hexane fractions [8325(N), II, and 8325( $\mathrm{pI}_{258}$ blaI $\left.{ }^{-}\right)$, III] were applied to activated silica gel $G$ plates together with standards of linoleic acid (I) and methyl linoleate (IV). The plate was developed in hexane/ethanol $(3: 1$, by vol.) and then exposed to iodine vapour. Spots were marked and the plate was autoradiographed. Radioactive areas of gel were scraped off and counted. Shaded spots correspond to radioactive material as determined by autoradiography.

mediately on glycerol starvation (Mindich, 1971). Therefore, a study of the effect of linoleic acid on growth immediately after glycerol starvation should indicate whether or not linoleic acid has to be incorporated into lipid prior to inhibiting growth.

First, the incorporation of $\left[1-{ }^{14} \mathrm{C}\right]$ linoleic acid into TCA-precipitated material by $147-$ $92 \mathrm{~S} 4 \mathrm{glyc}$ was studied. There was very little incorporation of linoleic acid in the absence of glycerol whereas glycerol-supplemented cultures, that exhibited the same growth inhibition, incorporated linoleic acid into membrane lipid (Fig. 7a). After $60 \mathrm{~min}$ in conditions of glycerol deprivation, the incorporation was only $6 \%$ of that with glycerol supplementation.

The presence of the PC plasmid potentiated the growth inhibitory properties of linoleic acid on the 147-92 strains. Like 147-92 S4glyc, 147-92 S4glyc $\left(\mathrm{pI}_{258}\right.$ bla $\left.\mathrm{I}^{-}\right)$incorporated only about $8 \%$ of linoleic acid into lipid during glycerol starvation compared with that under conditions of glycerol supplementation (Fig. $7 b$ ).

During the initial period following glycerol deprivation, linoleic acid inhibited the growth of both 147-92 S4glyc and 147-92 S4glyc $\left(\mathrm{pI}_{2 ; 8}\right.$ blaI $\mathrm{I}^{-}$) (Fig. 8). These experiments strongly suggest that it is linoleic acid itself that is the growth inhibitory species. 


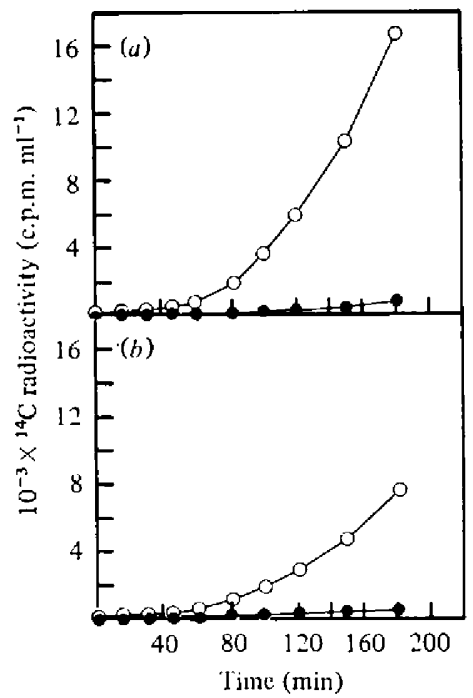

Fig. 7. Dependence of $\left[1{ }^{14} \mathrm{C}\right]$ linoleic acid incorporation on the presence of glycerol. Cultures of

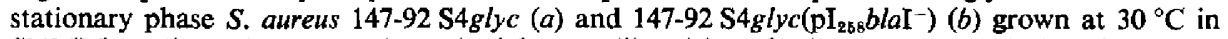
SNMM medium plus $20 \mu \mathrm{g}$ glycerol ml-1 were diluted into fresh warm SNMM plus glycerol to an $A_{675}$ of 0.05 . These cultures were grown at $30^{\circ} \mathrm{C}$ for three generations, then harvested by centrifugation, washed with warm SNMM without glycerol and finally resuspended in warm SNMM without glycerol. Samples of these cultures were added to flasks of SNMM containing $\left[11^{14} \mathrm{Cl}\right.$ linoleic acid $\left(5 \mu \mathrm{g} \mathrm{ml}^{-1}\right)$ with or without glycerol, to give an $A_{875}$ of about 0.05 . Incorporation of $\left[1{ }^{14} \mathrm{C}\right] \mathrm{linoleic}$ acid into TCA-precipitated material was followed as described in Methods. $O$, With glycerol; $\bullet$, without glycerol.

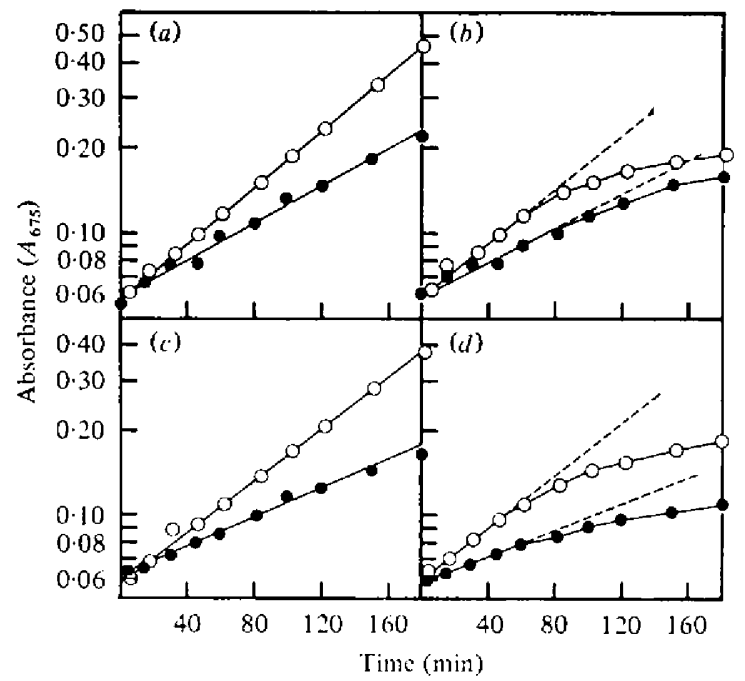

Fig. 8. Effect of linoleic acid on growth following glycerol deprivation of $S$. aureus 147-92 S4glyc and 147-92 S4glyc( $\left.\mathrm{pl}_{258} b l a \mathrm{I}^{-}\right)$. Cultures were grown as described in Fig. 7, and flasks of SNMM with or without glycerol $\left(20 \mu \mathrm{g} \mathrm{ml}^{-1}\right)$ and with or without linoleic acid $\left(5 \mu \mathrm{g} \mathrm{ml}^{-1}\right)$ were inoculated to give an $A_{675}$ of about 0.05 . Growth was followed at $30^{\circ} \mathrm{C}$. $\bigcirc$, Controls; $\bullet$, with linoleic acid. (a) 147-92 S4glyc with glycerol (growth inhibition $38 \%$ ); (b) 147-92 S4glyc without glycerol (initial growth inhibition $34 \%$ ); (c) 147-92 S4glyc(p⿰ $\left.{ }_{258} b l a I^{-}\right)$with glycerol (growth inhibition $45 \%$ ); (d) 147-92 S4glyc( $\mathrm{pI}_{258} b l a \mathbf{l}^{-}$) without glycerol (initial growth inhibition $50 \%$ ). 


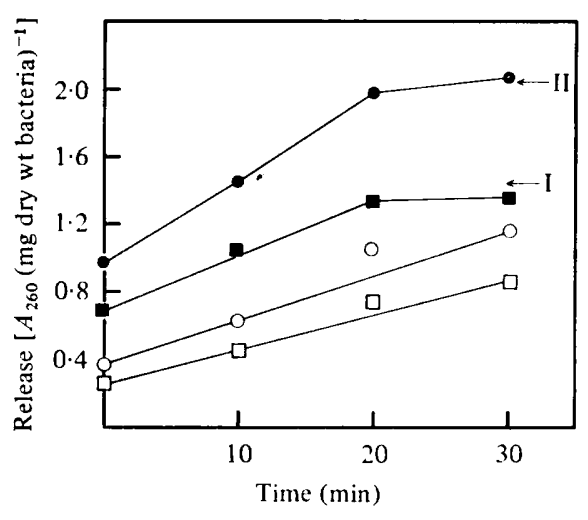

Fig. 9

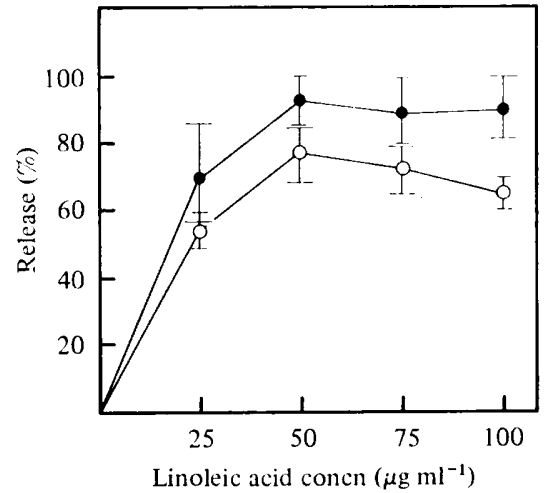

Fig. 10

Fig. 9. Release of $260 \mathrm{~nm}$-absorbing material from $S$. aureus by linoleic acid. Leakage of $260 \mathrm{~nm}$ absorbing material from $S$. aureus $8325(\mathrm{~N})(\mathrm{O}, \mathrm{O})$ and $8325\left(\mathrm{pl}_{258}\right.$ bla $\left.\mathrm{I}^{-}\right)(\square, \square)$ was measured as described in Methods. Linoleic acid (final concn $50 \mu \mathrm{g} \mathrm{ml}^{-1}$ ) was added in a small volume of ethanol $(1 \%, v / v)$; ethanol (to $1 \%, v / v)$ was added to control suspensions. Arrows I and II indicate the amount of $260 \mathrm{~nm}$-absorbing material released per mg dry wt bacteria after 15 min boiling, from $8325(\mathrm{~N})$ and $8325\left(\mathrm{pl}_{258}\right.$ blaI $\left.^{-}\right)$, respectively. $\bigcirc, \square$, Controls; O, $\square$, with linoleic acid.

Fig 10. Dependence of release of $260 \mathrm{~nm}$-absorbing material from $S$. aureus on the linoleic acid concentration. The release of $260 \mathrm{~nm}$-absorbing material from suspensions of $S$. aureus $8325(\mathrm{~N})(\mathrm{O})$ and $8325\left(\mathrm{pl}_{258} b_{l a I^{-}}\right)(O)$ was measured as described in Fig. 9. Ethanol was present in all suspensions at $1 \%(\mathrm{v} / \mathrm{v})$ final concentration. The release of material, expressed as a percentage of the material released by boiling, was measured after $15 \mathrm{~min}$ incubation at $30^{\circ} \mathrm{C}$. The results of three independent experiments are shown.

\section{Release of $260 \mathrm{~nm}$-absorbing material by linoleic acid}

The growth inhibitory properties of linoleic acid may be due to its strong surfactant activity (Dervichian, 1954). Salton (1951) has previously shown that $S$. aureus is particularly susceptible to the cationic detergent cetyltrimethylammonium bromide, which causes the release of $260 \mathrm{~nm}$-absorbing material; linoleic acid may behave in a similar way.

Leakage of $260 \mathrm{~nm}$-absorbing material from $S$. aureus $8325(\mathrm{~N})$ and $8325\left(\mathrm{pI}_{258}\right.$ blaI $\left.{ }^{-}\right)$was measured by the method of Salton (1951), except that mid-exponential phase bacteria were used instead of stationary phase bacteria, and all experiments were conducted in $50 \mathrm{~mm}$ -

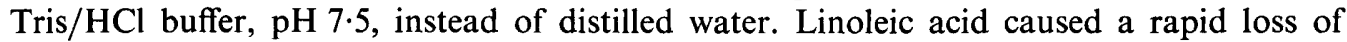
$260 \mathrm{~nm}$-absorbing material from both $8325(\mathrm{~N})$ and $8325\left(\mathrm{pI}_{258}\right.$ bla $\mathrm{I}^{-}$) (Fig. 9). After the very rapid initial loss, the release was linear for $20 \mathrm{~min}$, and by $30 \mathrm{~min}$ linoleic acid had resulted in the loss of material equivalent to that caused by boiling. It is interesting to note th $8325(\mathrm{~N})$ had more $260 \mathrm{~nm}$-absorbing material per $\mathrm{mg}$ dry wt bacteria than did 8325$\left(\mathrm{pI}_{258}\right.$ blaI $\left.^{-}\right)$. This release of $260 \mathrm{~nm}$-absorbing material was dependent on the linoleic acid concentration; it was maximal at linoleic acid concentrations greater than $50 \mu \mathrm{g} \mathrm{ml}^{-1}$ (Fig. 10). Strain $8325\left(\mathrm{pI}_{258}\right.$ blaI $\mathrm{I}^{-}$) lost a higher proportion of this material (85 to $100 \%$ ) compared with that released by boiling than did $8325(\mathrm{~N})(68$ to $85 \%)$. Consistent with the growth inhibition studies (Fig. 1), stearic acid at a similar concentration did not cause release of $260 \mathrm{~nm}$-absorbing material from $S$. aureus (Table 2).

If linoleic acid is behaving as a surfactant in this system, it may be altering the interfacial tension between the bacterial membrane and the bulk aqueous phase of the growth medium. In a model system, Peters (1931) studied the changes of the interfacial tension between a solution of stearic acid in benzene and an aqueous buffer solution. Increasing the $\mathrm{pH}$ of the aqueous phase from $5 \cdot 5$ did not significantly change the interfacial tension until the $\mathrm{pH}$ was $7 \cdot 5$ to $8 \cdot 0$. The effect of $\mathrm{pH}$ on the growth inhibition of $S$. aureus was therefore studied. Since the growth was being measured, the $\mathrm{pH}$ of the growth medium could not be varied far 
Table 2. Release of $260 \mathrm{~nm}$-absorbing material from $S$. aureus by stearic and linoleic acids

$\begin{array}{lcc} & \begin{array}{c}\text { Release }\left[A_{260}\left(\mathrm{mg} \mathrm{dry} \mathrm{wt}^{-1}\right]\right. \\ \text { after } 15 \mathrm{~min}\end{array} \\ \text { Fatty acid* } & \overbrace{\text { Control (none) }}^{8325(\mathrm{~N})} & 8325\left(\mathrm{pI}_{258} \text { blaI }^{-}\right) \\ \text {Linoleic acid } & 0.76 & 0.52 \\ \text { Stearic acid } & 1.57 & 1.21 \\ \text { (1) } & 0.71 & 0.52\end{array}$

* Fatty acids (final concn $50 \mu \mathrm{g} \mathrm{ml}^{-1}$ ) were added in a small volume of ethanol (final concn $1 \%, \mathrm{v} / \mathrm{v}$ ). This concentration of ethanol was present in the control suspensions.

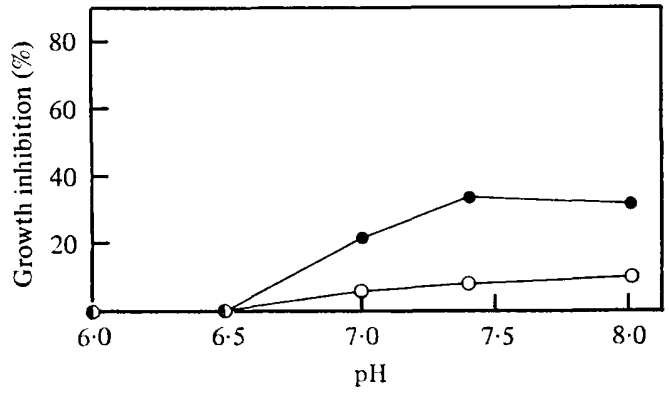

Fig. 11. Effect of pH on growth inhibition produced by linoleic acid. Cultures of stationary phase $S$. aureus $8325(\mathrm{~N})(\bigcirc)$ and $8325\left(\mathrm{pI}_{258}\right.$ blaI $\left.^{-}\right)(\bigcirc)$ grown at different $\mathrm{pH}$ values at $30^{\circ} \mathrm{C}$ were diluted into fresh warm CY medium at the same pH to an $A_{675}$ of $0 \cdot 1$ and grown for three generations. The growth inhibition produced by $3 \mu \mathrm{g}$ linoleic acid $\mathrm{ml}^{-1}$ was then determined as described in Fig. 1.

from neutrality. Between $\mathrm{pH} 6.0$ and 8.0 , the mean generation time of control cultures did not alter significantly, and the $\mathrm{pH}$ of the growth medium did not change over the duration of the experiment from that set at the beginning. At pH 6.0 and 6.5, linoleic acid did not inhibit growth (Fig. 11). Between pH 7.0 and 8.0 , growth inhibition became evident, with the highest inhibition observed at $\mathrm{pH} 7 \cdot 4$ (pH of $\mathrm{CY}$ medium) and $8 \cdot 0$. This $\mathrm{pH}$ effect was similar for both $8325(\mathrm{~N})$ and $8325\left(\mathrm{pI}_{258}\right.$ blaI $\left.\mathrm{I}^{-}\right)$, except that the latter was more inhibited.

\section{DISCUSSION}

Linoleic acid is rapidly taken up and incorporated into the phospholipids of $S$. aureus $8325(\mathrm{~N})$ and $8325\left(\mathrm{pI}_{258} b l a \mathrm{I}^{-}\right)$. This incorporation is high, equivalent to approximately $0.9 \%$ of the bacterium's dry weight after a generation of growth (about $16 \%$ of the fatty acid composition). Since the membranes of $S$. aureus have a low UFA content [principally monoenoic and only about $2.8 \%$ of the fatty acid composition (White \& Frerman, 1968)], the fivefold increase in the UFA content of the bacterial membrane phospholipids after growth in linoleic acid-containing medium might be expected to alter the permeability properties of the bacterial membrane. As the incorporated linoleic acid is not significantly metabolized, linoleic acid-containing lipid could certainly be deleterious to the bacterium. However, experiments using the glycerol auxotroph of $S$. aureus, 147-92 S4glyc, have shown that incorporation of linoleic acid into membrane lipid is not essential for growth inhibition. The period of growth following glycerol deprivation was still inhibited to the same degree by linoleic acid as were glycerol-supplemented cultures, even though the former cultures incorporated less than $10 \%$ of the amount of linoleic acid incorporated by glycerol-supplemented cultures. Thus, free linoleic acid itself seems to be the growth inhibitory substance and not linoleic acid-containing membrane lipid. 
Linoleic acid does alter the permeability of $S$. aureus membranes, since there is rapid leakage of $260 \mathrm{~nm}$-absorbing material from treated bacteria. This material is probably similar to that previously identified as consisting of nucleotides and amino acids, and representing 'pool' material (Salton, 1951). In agreement with the growth inhibition studies, stearic acid does not produce a similar permeability increase. It is possible that the primary effect of linoleic acid may be to increase the membrane permeability to low molecular weight solutes, e.g. ions, and that the observed $260 \mathrm{~nm}$-absorbing material leakage is a secondary effect.

The altered permeability could explain the inhibition of synthesis of macromolecules and oxygen uptake. One possibility is that the organization of proteins such as permeases and cytochromes within the membrane is disrupted by linoleic acid and this results in cessation of synthetic activity. Although it is known that long-chain fatty acids can uncouple oxidative phosphorylation (Pressman \& Lardy, 1956; Hülsmann et al., 1960; Borst et al., 1962), it is possible for an uncoupler of oxidative phosphorylation to cause inhibition of oxygen uptake of bacteria when energy is necessary for the uptake of carbon sources and metabolites. For $S$. aureus grown on glucose as its carbon source, energy is necessary for glucose uptake via the phosphotransferase system (see Postma \& Roseman, 1976). Under the experimental conditions used, linoleic acid behaves as an inhibitor of oxidative phosphorylation although it may be, in addition, an uncoupler.

Linoleic acid may increase membrane permeability as a result of its surfactant properties. The $\mathrm{pH}$ dependence of growth inhibition by linoleic acid supports this idea since linoleic acid may be decreasing the interfacial tension at the bacterial lipid membrane-aqueous medium interface. As the $\mathrm{p} K_{\mathrm{a}}$ of linoleic acid is about 5.0 (Smith \& Tanford, 1973), alteration of the pH between 6.0 and 8.0 will not substantially alter the degree of ionization of the fatty acid but the interfacial tension can vary widely in this $\mathrm{pH}$ range in model systems, as shown by Peters (1931). Altenbern (1977a) has recently reported a similar $\mathrm{pH}$ dependence of growth inhibition by linoleic acid.

Stearic acid may not inhibit growth because, at $30^{\circ} \mathrm{C}$, it is a much poorer surfactant than linoleic acid (see Dervichian, 1954). Only at temperatures of $70^{\circ} \mathrm{C}$ or higher do linoleic and stearic acids have similar surfactant properties. Further evidence supporting these ideas is that UFAs caused greater expansions of monolayers of $S$. aureus lipid than did saturated fatty acids under similar conditions (Gale \& Llewellin, 1971).

The leakage experiments have indicated a possible mechanism that may account for the difference in linoleic acid sensitivity between $8325(\mathrm{~N})$ and its PC plasmid-containing derivative. The permeability of $8325\left(\mathrm{pI}_{258}\right.$ bla $\left.\mathrm{I}^{-}\right)$membranes is affected more than those of $8325 \mathrm{~N}$ such that pool material is lost at a higher rate. This is the only observation so far that could account for the differential linoleic acid sensitivity. Some component-either the PC plasmid itself or a component determined by the plasmid - appears to affect the membranes of $8325\left(\mathrm{pI}_{258}\right.$ bla $\left.\mathrm{I}^{-}\right)$bacteria so that they are more sensitive to the effects of linoleic acid. Such a component appears to be the membrane-bound penicillinase protein itself (D. L. A. Greenway \& K. G. H. Dyke, unpublished).

The uptake studies have highlighted a number of interesting points. (1) The kinetic properties of uptake of linoleic acid by $8325(\mathrm{~N})$ and $8325\left(\mathrm{pI}_{258}\right.$ bla $\left.\mathrm{I}^{-}\right)$are similar but not identical. The PC plasmid may specify a different or altered uptake system since the $K_{\mathrm{m}}$ is lower (i.e. higher affinity) and the $V_{\max }$ is higher than that of the corresponding plasmidnegative strain. It seems unlikely that these differences are sufficient to account for the differing UFA sensitivities of the two strains, especially when considered with the properties of an isolated linoleic acid resistant mutant LAR-1 (D. L. A. Greenway \& K. G. H. Dyke, unpublished). (2) The lack of metabolism of linoleic acid by $S$. aureus suggests that this bacterium has a very limited ability to metabolize such compounds by, for example, $\beta$-oxidation, and this may account for their high level of incorporation into membrane phospholipids. Similar observations have been made by others with $\left[1-{ }^{14} \mathrm{C}\right]$ oleic acid 
(Hedström, 1975) and $\left[{ }^{14} \mathrm{C}\right]$ stearic acid (Gale \& Folkes, 1967). This finding apparently excludes the possibility that the difference in linoleic acid sensitivity between $8325(\mathrm{~N})$ and $8325\left(\mathrm{pI}_{258}\right.$ bla $\left.\mathrm{I}^{-}\right)$results from $8325(\mathrm{~N})$ bacteria having the ability to metabolize linoleic acid to some less toxic form. (3) Incorporation of linoleic acid into membrane lipid may be a kind of detoxification mechanism. This may explain the discrepancy between the lowest concentration required to produce growth inhibition (about $3 \mu \mathrm{g} \mathrm{ml}^{-1}$ ) and the $K_{\mathrm{m}}$ for linoleic acid uptake (about $0.5 \mu \mathrm{g} \mathrm{ml}^{-1}$ ). The maximum rate of linoleic acid incorporation (i.e. $V_{\max }$ ) occurs at a concentration of about 1.5 to $3.0 \mu \mathrm{g} \mathrm{ml}^{-1}$, so that at this concentration linoleic acid is efficiently incorporated into membrane lipid. At higher concentrations (greater than $3 \mu \mathrm{g} \mathrm{ml}^{-1}$ ), this incorporation appears insufficient to prevent linoleic acid from interacting with its sensitive site. Staphylococcus aureus is known to be able to tolerate quite large variations in its fatty acid composition without any apparent deleterious effect (Váczi et al., 1967; Altenbern, 1977b).

D. L. A.G. was the recipient of an MRC Studentship for Training in Research Methods.

\section{REFERENCES}

Altenbern, R. A. (1977a). Effect of exogenous fatty acids on growth and enterotoxin $\mathrm{B}$ formation by Staphylococcus aureus 14458 and its membrane mutant. Canadian Journal of Microbiology 23, 389-397.

AltenkerN, R. A. (1977b). Cerulenin-inhibited cells of Staphylococcus aureus resume growth when supplemented with either a saturated or an unsaturated fatty acid. Antimicrobial Agents and Chemotherapy 11, 574-576.

Borst, P., Loos, J. A., Christ, E. J. \& Slater, E. C. (1962). Uncoupling activity of long-chain fatty acids. Biochimica et biophysica acta 62 , 509-518.

Butcher, G. W., KING, G. \& DYKe, K. G. H. (1976). Sensitivity of Staphylococcus aureus to unsaturated fatty acids. Journal of General Microbiology 94, 290-296.

DERVICHIAN, D. G. (1954). The surface properties of fatty acids and allied substances. In Chemistry of Fats and Other Lipids, vol. 2, pp. 193-242. Edited by R. T. Holman, W. O. Lundberg \& T. Malkin. London: Academic Press.

DitTMer, J. C. \& Lester, R. L. (1964). A simple specific spray for detection of phospholipids on thin layer chromatograms. Journal of Lipid Research 5, 126-127.

Eisenthal, R. \& CoRnish-Bowden, A. (1974). The direct linear plots - a new graphical procedure for estimating enzyme kinetic parameters. Biochemical Journal 139, 715-720.

Freese, E., Sheu, C. W. \& Galliers, E. (1973). Function of lipophilic acids as antimicrobial food additives. Nature, London 241, 321-325.

Galbraith, H. \& Miller, T. B. (1973a). Effect of metal cations and $\mathrm{pH}$ on the antibacterial activity and uptake of long-chain fatty acids. Journal of Applied Bacteriology 36, 635-646.

Galbraith, H. \& Miller, T. B. (1973b). Physicochemical effects of long-chain fatty acids on bacterial cells and their protoplasts. Journal of Applied Bacteriology 36, 647-658.

Galbraith, H. \& Miller, T. B. $(1973 c)$. Effect of long-chain fatty acids on bacterial respiration and amino acid uptake. Journal of Applied Bacteriology 36, 659-675.

Galbraith, H., Miller, T. B., Paton, A. M. \& Thompson, J. K. (1971). Antibacterial activity of long-chain fatty acids and their reversal with $\mathrm{Ca}^{2+}, \mathrm{Mg}^{2+}$, ergocalciferol and cholesterol. Journal of Applied Bacteriology 34, 803-813.

Gale, E. F. \& Folkes, J. P. (1967). Effects of lipids on the accumulation of certain amino acids by Staphylococcus aureus. Biochimica et biophysica acta 144, 461-466.

Gale, E. F. \& Llewellin, J. M. (1971). Effect of unsaturated fatty acids on aspartate transport in Staphylococcus aureus and on staphylococcal lipid monolayers. Biochimica et biophysica acta 233, 237-242.

Hancock, R. \& PARK, J. T. (1958). Cell wall synthesis by Staphylococcus aureus in the presence of chloramphenicol. Nature, London 181, 10501052.

HedSTRÖM, S. A. (1975). Lipolytic activity of Staphylococcus aureus strains from cases of human chronic osteomyelitis and other infections. Acta pathologica et microbiologica scandinavica B83, 285-292.

HülsmanN, W. C., Elliott, W. B. \& Slater, E. C. (1960). Nature and mechanism of action of uncoupling agents present in mitochrome preparations. Biochimica et biophysica acta 39, 267276.

Johnston, L. H. \& Dyke, K. G. H. (1971). Stability of penicillinase plasmids in Staphylococcus aureus. Journal of Bacteriology 107, 63-73.

KAYE, G. W. C. \& LABY, T. H. (1966). Tables of Physical and Chemical Constants, 13th edn. London: Longmans.

MiNDICH, L. (1971). Induction of Staphylococcus aureus lactose permease in the absence of glycerolipid synthesis. Proceedings of the National Academy of Sciences of the United States of America 68, 420-424.

Mitsuhashi, S. Hashimoto, H., Kono, M. \& MORIMURA, M.(1965). Drugresistance of staphylococci. II. Joint elimination and joint trans- 
duction of penicillinase production and resistance to macrolide antibiotics. Journal of Bacteriology 89, 988-992.

NiEmAN, C. (1954). Influence of trace amounts of fatty acids on the growth of microorganisms. Bacteriological Reviews 18, 147-163.

Nikaido, H. (1976). Outer membrane of Salmonella typhimurium: transmembrane diffusion of some hydrophobic substances. Biochimica et biophysica acta 433, 118-132.

Novick, R. P. (1963). Analysis by transduction of mutations affecting penicillinase formation in Staphylococcus aureus. Journal of General Microbiology 33, 121-136.

Peters, R. A. (1931). Interfacial tension and proton concentration. Proceedings of the Royal Society 133A, 140-154.

Postma, P. W. \& Roseman, S. (1976). The bacterial phosphoenolpyruvate:sugar phosphotransferase system. Biochimica et biophysica acta 457 , 213-257.

Pressman, B. C. \& Lardy, H. A. (1956). Effect of surface active agents on the latent ATPase of mitochondria. Biochimica et biophysica acta 21, 458-466.

Roantree, R. J., Kuo, T., MacPhee, D. G. \& STOCKER, B. A. D. (1969). The effect of various rough lesions in Salmonella typhimurium upon sensitivity to penicillins. Clinical Research 17, 157.

Salton, M. R. J. (1951). The adsorption of cetyltrimethylammonium bromide by bacteria, its action in releasing cellular constituents and its bactericidal effects. Journal of General Microbiology 5, 391-404.

Schlecht, S. \& Schmidt, G. (1970). Möglichkeiten zur Differenzierung von Salmonella-R-Formen mittels Antibiotica und antibakterieller Farbstoffe. Zentralblatt für Bakteriologie, Parasiten- kunde, Infektionskrankheiten und Hygiene, Originale 212, 505-511.

Schmidt, G., Schlecht, S. \& Westphal, O. (1969). Investigations on the classification of Salmonella $\mathrm{R}$ forms. 3. Communication: Classification of $S$. minnesota mutants by chemical agents. Zentralblatt für Bakteriologie, Parasitenkunde, Infektionskrankheiten und Hygiene, Originale 212, 88-96.

Sheu, C. W. \& Freese, E. (1973). Lipopolysaccharide layer protection of Gram-negative bacteria against inhibition by long-chain fatty acids. Journal of Bacteriology 115, 869-875.

Sheu, C. W., Salomon, D., Simmons, J. L., SreevalSON, T. \& FREESE, E. (1975). Inhibitory effects of lipophilic acids and related compounds on bacteria and mammalian cells. Antimicrobial Agents and Chemotherapy 7, 349-363.

SmITH, R. \& TANFORD, C. (1973). Hydrophobicity of long chain $n$-alkyl carboxylic acids as measured by their distribution between heptane and aqueous solutions. Proceedings of the National Academy of Sciences of the United States of America 70, 289-293.

VÁCZI, L., RÉdAI, I. \& RÉTHY, A. (1967). Changes in the fatty acid composition of Staphylococcus aureus under various cultural conditions. Acta microbiologica Academiae scientiarum hungaricae 14, 293-298.

White, D. C. \& Frerman, F. E. (1967). Extraction, characterization and cellular localization of the lipids of Staphylococcus aureus. Journal of Bacteriology 94, 1854-1867.

White, D. C. \& Frerman, F. E. (1968). Fatty acid composition of the complex lipids of Staphylococcus aureus during the formation of membrane bound electron transport system. Journal of Bacteriology 95, 2198-2209. 